\title{
FOSTERING THE LISTENING SKILL OF INDONESIAN NINTH GRADERS OF JUNIOR HIGH SCHOOL THROUGH DICTOGLOS
}

\author{
Ni Made Leniadi \\ SMP Negeri 1 Rendang \\ lenimade82@gmail.com
}

\begin{abstract}
This study aimed at improving the students' listening skill through Dictoglos. The design of the study was a classroom based action research which was carried out in two cycles, each comprising two teaching learning sessions and one post-test. The subjects were the ninth year students of SMP Negeri 1 Rendang at class IX D. The data were collected through listening test and analyzed descriptively. The results revealed that the students' listening skill could be improved through the use of Dictoglos as proven by attainment of the class success indicator(class learning mastery level) $90 \%$ by the end of cycle 2 , which was improving from $67 \%$ in cycle 1 and $47 \%$ in the pretest.
\end{abstract}

Key Words: Listening, Dictoglos

\section{Introduction}

Languages are means of communication.As individual, people use languagesto expressideas, thoughts, andknowledgeto others. They also use them for socialising (Suwarno, 2002:4). Due to that reason, languages are very important to be taught at school. One of them is english. Learning English is very important because it increases the chances of getting a good job in this era. Many countries include English in their school syllabus and at a young age, children start to learn english.

Indonesian junior high school students learn the four skills of English that is listening, speaking, reading and writing. Listening is the basis for the development of all other skills. It is the main channel through which students makes first contact with the target language and its culture.That is why listening skill has a very important role in the learning process (Etman \& Zaida, 2009: 1).

Moreover, Etman dan Zaida (2009: 1)explain that the main objective of listening comprehension practice in junior high school level is that the students should learn to function successfully in real life situations. BSNP (2007: 225) states that in detail, the goal of learning listening in the first semester of the ninth grade is that the students are able to gain information from different kinds of listening texts or genres. It includes dialogues about certainty, asking for repetition, giving attention, and showing amazement. There are also short funtional texts (advertisement and announcement) andshort essays (procedure dan report).Many students thought that achieving such purposes are not an easy job. For them, listening is the most difficult skill to master. One of the main reason causing the problem is the difficulties in catching the words they 
listen because it is not their mother tongue.

The fenomena were also found in SMP Negeri 1 Rendang, specifically the ninth graders in the first semester (class IXD)in the academic year of 2018/2019. It can be seen from the result of the pretest.The result showed that only $47 \%$ students could pass the passing grade. The class learning mastery levelthat is $85 \%$ as stated in the curriculum (KTSP) of SMP Negeri 1 Rendang had not achieved yet.

It was found out that the reasons causing the problem were the students' mental blocks and their lack of vocabularies. The students did not have many chances to collaborate in the learning process that stressed them. Moreover, listening was new for them since it was not effectively taught in the elementary school. While listening, the students suddenly decided that they did not understand what is being said. They convinced themselves that they were not able to understand spoken English well and created problems for themselves. Beare in Parianingsih (2008:1) calls it mental block. The students mastery of vocabularies was also very poor. They found difficulties in memorizing the words because English is not their mother tongue.

Considering the facts, Dictoglos was used to overcome the problems. Herrell dan Jordan (2004:242) describe Dictoglosas a strategy that focuses on fluent academic language and supports students in listening and recalling good English language models which is especially effective with English language learners. It involved students in listening to repeated readings of English text. At first they just listen. Then, on subsequent readings, they take down words as much of the text as possible. After that they get together in pairs and again in fours to combine their notation and re-create as much of the text as possible. The activitiy provides an authentic reason for communication and practice in re-creating, rewriting and rereading English text. Therefore, this strategy provides more interesting listening activities that can reduce students' mental block and enrich their vocabularies.

Parianingsih (2008) also had applied Dictoglos to overcome the problem faced in listening by students SMP Negeri 2 Kediri in the academic year of 2008/2009. The use of Dictoglos was proven to be very effective to improve her students' listening skill.

Considering the explanation stated previously, the aim of this study was improving the students' listening skill through Dictoglos.

\section{Methods}

Since this study aimed at improving the students' listening skill,a classroom based action research was conducted. Kemmis dan McTaggart in Parianingsih (2008:9) defines this research as a cyclic process that consists of planning, action, observation, and reflection. First, the researcher develops a plan for improvement, and then implements the plan. After that the effects of the plan are observed and documented. Finally there is a reflection done on the effects of the plan for further planning and action.

The subjects of this study, which was conducted in July to September 2018, 
were the first semester students of class IX D SMP Negeri 1 Rendangin the academic year of 2018/2019. The total subjects were 30 students consisting of 13 malesand 17 females. The students were chosen as the subjects of the study based on the preliminary observation conducted in which they encountered problems in listening.

Before the cycles were conducted, a pretest was administered to obtain the preliminary data about the student's listening skill. After that the cycles were carried out in two cycles, each comprising two teaching learning sessions and one post-test. The detail of the cycles can be seen as follows.

a. Planning.

In this stage the researcher made lesson plans and prepared instruments of the data collection in the form of listening test.

b. Action.

In conducting the treatment, the researcher simply followed the teaching scenario that had been set up. The followings were the major activities conducted in each session.

1) Reading the text aloud.

The researcher read the text aloud at a normal speaking pace. At first, the students were instructed to just listen carefully.

2) Rereading the text orally.

The researcher read the text twice more. The students were instructed to jot down the key words and phrases.

3) Pairing to re-create the text.

The researcher had the students work in pairs to re-create as much of the text as possible using the notes taken by each of the partners to write the texts as closely as possible to the original text as read by the researcher.

4) Working in groups of four.

The researcher had two pairs met together and reconstruct the text more completely. The aim was to re-create it as closely as possible to the original text.

5) Reading the re-created text.

The researcher had one member of each group to read their re-creation of the text and asked the other groups to see how closely it matched their versions. The students compared and discussed the works. After that they were given some questions about the text to be discussed.

\section{c. Observation}

The researcher did the observation toward the implementation of the action and the effects of it on students' listening skill.

d. Reflection

In this step, the data collected was analyzed descriptively to find out the strengths and the weaknesses of the treatment and to find out the solution for the problems or weaknesses found in the treatment.

The data was analyzed based on the score obtained by the students and the class learning mastery level which was calculated using the following formulas.
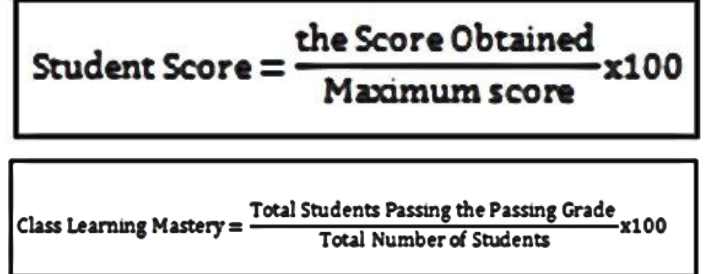
There were two success indicators used in this study as follows.

1. Individual Success Indicator. It is achieved if the students score is at least 75 because the passing grade (Kriteria Ketuntasan Minimal/KKM) in English of the ninth grade in the academic year of 2018/2019 is 75 .

2. Class Success Indicator.It is achieved if at least $85 \%$ of the students get score at least 75 because the curriculum (KTSP) of SMP Negeri 1 Rendang in the academic year of 2018/2019 states that the class learning mastery level (Ketuntasan Belajar Klasikal) is $85 \%$.

\section{Findings And Discussion}

From the data analysis, it was found out that the students' listening skill was improved after Dictoglos was conducted in the two cycles. The class learning mastery in the preliminary observation was only $47 \%$ and improved to $67 \%$ in cycle 1 and $90 \%$ in cycle 2 .

The improvements can be seen in the following graph.

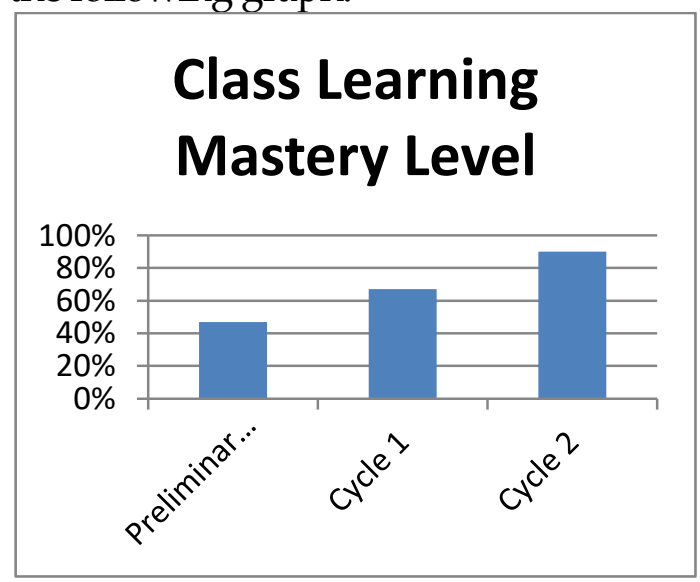

Figure 1.Class Learning Mastery

The problems found in the preliminary observation that is the students' mental blocks and the students lack of vocabularies can be overcome by implementing Dictoglos.However, the success indicator had not obtained yet in cycle 1. It was because some weaknesses found. Many students were not actively involved in the discussion andthe speaking pace was not consistent which made them difficult to catch the words.

Regarding the weaknesses, some different activities were done in the following cycle. The researcher used a recording text and motivated the students to be more actively involved in every discussion.

The efforts could made the students achieved 90\% class learning mastery level in cycle 2.It shows that the success indicators of this study had been achieved and students problems in listening had been overcome.

From the result gained, it can be concluded that Herrel dan Jordan (2004:242) is right. Dictoglos allows the students to works in groups. Thus, provides an authectic reason for communication and practice in recreating, rewriting and rereading English text. Therefore, it gives more interesting listening activities that can reduce students' mental block and enrich their vocabularies.

\section{Conclusions}

Dictoglos is an effective strategy for improving students' skill in listening that encourages them to focus on fluent academic language and supports them in recalling good English language models.

Dictoglos, particularly, could improve the listening skill of the first semester students (class IX D) of SMP Negeri 1 Rendang in the academic year of 2018/2019 . It was proven by attainment of the class success indicator 
$90 \%$ by the end of cycle 2 , which was improving from $67 \%$ in cycle 1 and $47 \%$

\section{References}

BSNP (Badan Standar Nasional Pendidikan). 2007. Kurikulum Tingkat Satuan Pendidikan Untuk Sekolah Mengengah Pertama dan Madrasah Tsanawiyah (Jilid 1). Jakarta: PT. Binatama Raya.

Etman, Djodi dan Nur Zaida. 2009. Teaching Listening. Jakarta: Ministry of National Education; Directorate General of Quality Improvement of Teachers and Education Personnel.

Herrell, Adrienne dan Michael Jordan. 2004. Fifty Strategies for in the pretest.

TeachingEnglish Language Learners $2^{\text {nd }}$ Edition. New Jersey: Pearson Education, Inc.

Parianingsih, I Gusti Ayu . 2008. Menggunakan Dictoglos Untuk Meningkatkan Kemampuan Mendengarkan Pebelajar SMP N 2 Kediri Pada Tahun Pelajaran 2008/2009. Penelitian Tindakan Kelas.

Suwarno, Pringgawidagda. 2002. Strategi Penguasaan Berbahasa. Yogyakarta: Adicita Karya Nusa 